\title{
THE RELATIONSHIP BETWEEN FOREIGN DIRECT INVESTMENT AND ECONOMIC GROWTH OF PAKISTAN
}

\author{
Rummana Zaheer ${ }^{*}$ \\ Shahana Kiramat ${ }^{* *}$
}

\begin{abstract}
Although it is very common to argue that the foreign direct investment is beneficial for the economic development of a nation. This exploration investigates the connection amongst FDI and economic development in case of Pakistan. In this study secondary data from 1985 to 2016 is taken to examine the relationship. The investigation included GDP as explained and exports and FDI as explanatory variables. To check data either it is stationary or not the study used Augmented Dickey Fuller test in our study. After making data stationary we have used OLS method to investigate the nature of relationship between the variables. Our results show that there is direct link amongst explained and explanatory variable. The findings also show that there is significant relationship between FDI and economic growth. After analyzing the calculations we came to know that foreign direct investment is a significant element for the economic development because it has positive impact and have significant relation with growth of an economy. Since FDI is an impressive element in economic development so, government should take steps to attract the foreign investors and make policies to encourage the trade liberalization to gain more from the foreign investment.
\end{abstract}

Keywords: Foreign direct investment, exports, development, GDP, investment, growth

\section{Introduction}

Foreign direct investment is a key component of economic integration and plays vital role in economic development. It is beneficial for investors and to the host country as well. FDI effects host countries in several ways. Firstly, we will discuss about the resource transfer effects that it contributes positively by providing the capital, technology and management resources which leads to raise the economic growth of a nation. Secondly, the employment effects, FDI provide employment opportunities to the host country. Balance-of-payment effects, FDI helps in two ways to run a current account surplus. It works as a supernumerary for imports of goods and services; resultantly it can enhance the balance of payment. Effects on competition and economic growth, due to FDI number of investors in the market increases and provides more choices to the consumer and it will leads to raise the level of competition. The expansion in level of rivalry within the market will drive down the prices, which makes the conditions for higher economic development.

\footnotetext{
"RummanaZaheer, Ph.D., Associate Professor, Department of Economics, University of Karachi

** Shahanakiramat M.Phil. Scholar, Department of Economics, University of Karachi
} 
When we talked about the flows of FDI in the economy of world then there are two ways to look at it, the outflows and the inflows of FDI. The out flow of FDI is the flow of investment out of a nation and the inflow of FDI is the entry of foreign direct investment into a nation. Both the flow and stock of FDI in the world have been increased over the preceding 35 years. The growth of foreign direct investment has rapidly increased and has left behind the world trade and world output. There are some reasons behind the rapid increase in foreign direct investment that many of firms still fear protectionist policies and shift towards the nation where they have to face less problems and risks. Foreign investors also prefer those countries where free market economies exist and encourage foreign direct investment.

In Pakistan, FDI played a pivotal part in growth of the economy and it is a measured as a major source to fulfill the gap between capital and human resources and goal achievement. But, for the last few years Pakistan is declining the foreign direct investment ratio behind which there are some considerable reasons, that there are not appropriate policies to encourage foreign investors. Lack of law and order is a crucial factor to lessen the foreign direct investment. There always remains political instability due to which economic conditions falls instantly. The tax structure in Pakistan for foreign investors is not feasible due to which investors have to bear high cost for investment, which is a discouraging strategy for foreign investors.

Koojaroenprasit ${ }^{1}$ also found significant and positive impact of FDI on economic growth of South Korea but, he found insignificant effect of domestic investment in economic growth in South Korea. The below table shows the performance of FDI in Pakistan since 2010 to 2017.

Table 1.1

Sector-Wise FDI in Pakistan (Million \$)

\begin{tabular}{|l|r|r|r|r|r|r|r|}
\hline Sectors & $\mathbf{2 0 1 0 - 1 1}$ & $\mathbf{2 0 1 1 - 1 2}$ & $\mathbf{2 0 1 2 - 1 3}$ & $\mathbf{2 0 1 3 - 1 4}$ & $\mathbf{2 0 1 4 - 1 5}$ & $\mathbf{2 0 1 5 - 1 6}$ & $\mathbf{2 0 1 6 - 1 7}$ \\
\hline Oil \& Gas & 512.2 & 629.4 & 559.6 & 502 & 300.5 & 248.9 & 157.6 \\
\hline $\begin{array}{l}\text { Financial } \\
\text { Business }\end{array}$ & 310.1 & 64.4 & 314.2 & 192.8 & 256.4 & 289 & 64.3 \\
\hline Textiles & 25.3 & 29.8 & 10 & -0.2 & 43.9 & 20 & 15.1 \\
\hline Trade & 53 & 25.3 & 5.7 & -3.2 & 50.5 & 26.8 & 31.6 \\
\hline Construction & 61.1 & 72.1 & 46 & 28.8 & 53.5 & 46.7 & 467.7 \\
\hline Power & 155.8 & -84.9 & 28.4 & 71.4 & 282.2 & $1,159.20$ & 795.4 \\
\hline Chemicals & 30.5 & 96.3 & 71.6 & 94.9 & 60.3 & 88.5 & 12.6 \\
\hline Transport & 104.6 & 18.7 & 44.1 & 2.7 & 6.2 & 70.2 & 53.5 \\
\hline $\begin{array}{l}\text { Communicatio } \\
\text { n (IT Telecom) }\end{array}$ & -34.1 & -312.6 & -385.7 & 434.2 & 40.1 & 246.8 & 28.6 \\
\hline
\end{tabular}

Source: Board of Investment Pakistan

\footnotetext{
${ }^{1}$ Koojaroenprasil "The Impact of Foreign Direct Investment on Economic Growth: A Case Study of South Korea". (Thailand: International Journal of Business and Social Science , 2012), Vol. 3 No.21; pp. 8-19
} 
From the above table we can found that Pakistan has decreased FDI in various sectors. If we compare the data of 2010-11 with 2016-17 then it is clearly highlighted that oil and gas has decline from $\$ 512.2$ million to $\$ 157.6$ million. Likewise, financial business, textile, trade, chemicals, transport and other sectors has been also declined by adverse ratio. Here we can see a significant increase in FDI in some sectors. In power there is a robust increase in fiscal year 2015-16 from \$282.2 million to \$1159.20 million, and in construction sector we can see a significant rise in fiscal year 2016-17 from $\$ 46.7$ million to \$ 467.7 million.

Hussain and Haque ${ }^{2}$ empirically analyze the foreign direct investment, trade balance and growth in context of Bangladesh. They take secondary data from 1973 to 2014. By utilizing vector correction model show, they found the outcome that FDI and trade have a significant role and thought about both as key elements of the economy.

Borensztein, Lee and Gregorio ${ }^{3}$ discuss the effects of foreign direct investment in economic growth. The data has been taken from 69 developing countries and show the effect of inflow of investment from various industrial countries. The findings show that Foreign Direct Investment is an essential factor of technology transfer and it contributes more than the domestic investment in the economic growth of a nation

Javid $^{4}$ examines the role of foreign direct investment in growth of economy of Pakistan. The research used an Autoregressive distributed lag-error correction model approach to know about the impact of long and short run. The data from 1966 to 2014 has been taken. The results described that foreign direct investment have direct and significant role in short run and in long run.

Saqib, Rafique and Masnoon ${ }^{5}$ studied about the effects of economic growth of FDI in context of Pakistan. The data of 30 years has been taken from 1981 to 2010. In this study FDI, debts, trade and domestic investment is taken as explanatory variables. OLS method has been used in the study. Their findings show that, economy of Pakistan is negatively affected by FDI while the local investments have benefited the country.

Alfaro $^{6}$ studied about the FDI and its impact on growth of a nation. In this research multiple regression models has been utilized to investigate the relationship by taking the data of 47 countries. His results showed that the impact of FDI is different for different sectors. Foreign direct investment is beneficial for manufacturing sector and has negative

\footnotetext{
${ }^{2}$ Hussain and Haque Foreign Direct Investment, Trade, and Economic Growth: An Empirical Analysis of Bangladesh. (USA: MDPI, 2016).

${ }^{3}$ Borensztein, Gregorio and Lee, "How does foreign direct investment affect economic growth.", Journal of International Economics, (1998), pp 115-135

${ }^{4}$ Javed, Sher, Awan and Ashfaq": Foreign Direct Investment, Trade And Economic Growth": A Comparison of Selected South Asian Countries, International Journal of Humanities and Social Science, (USA: 2012), vol. 2 No.5; pp.115-135

${ }^{5}$ Saqib, Masnoon and Rafique "impact of FDI on economic growth of Pakistan.", Advances in Management \& Applied Economics, (Pakistan: 2013), vol.3, no.1, 2013, 35-45

${ }^{6}$ Alfaro, Chanda, Ozken and Syek , "How does Foreign Direct Investment promote economic growth?" Exploring the Effects of Financial Markets on Linkages. Journal of Development Economics, (USA: 2000), pp.242-256
} 
effect on growth for primary sector. They also found that the effect of services sector is ambiguous.

Jaffri et $a l^{7}$ explore the contribution of FDI influxes on trade balance for the time of 1983 to 2011 in context of Pakistan. This study used autoregressive distributive log model (ARDL). They kept income outflows FDI and current account balance excluding current account transfers as variables. He found that rise in FDI leads to increase in income outflows and degrades trade balance except contemporary account transfers in long run.

Alfaro et al. ${ }^{8}$ found a significant part of foreign direct investment in subsidizing the growth of an economy while, level of expansion of local financial markets is essential for these positive effects to be recognized. The data from 1981 to 1997 has been taken from 39 countries. Multiple regression model has been wont to analyze the varied links among FDI, monetary markets.

Malik and Naseem also investigate about FDI in Pakistan. Durbin-Watson test, regression analysis, correlation and Co-integration analysis has been accustomed notice the long run relationship between the variables. They take published data from 2008 to 2013 of Pakistan. From their analysis it is found that foreign direct investment, domestic capital and openness of trade have positive role in growth processes.

Irfan et al. ${ }^{9}$ described the impact of FDI, domestic investment in Pakistan. The study takes data for the time of 1976 to 2010.Johnson cointegration approach is applied to look at the long-term relationship among the variables. They get the results that there is existence of bidirectional causality among domestic investment and FDI.

Behname $^{10}$ explores the impact of FDI and economic growth in Southern Asia. He estimated the data for the time of 1977-2009. This study used FDI, human capital, economic infrastructure, population, technology gap, inflation and GDP as variables. This study used ADF test to see the stationary of data. The study found that FDI have progressive impact on GDP whereas inflation, technology gap and population have inverse relation with economic growth.

Koojaroenprasit ${ }^{11}$ investigate the significance of FDI in economic progress of South Korea. FDI, employment, export and human capital has been used as variables. The data from1980to 2009 has been used. The study used multiple regression model and found

\footnotetext{
${ }^{7}$ Jaffri, Asghar, Ali and Asjid "Foreign Direct Investment and Current Account Balance of Pakistan.", Pakistan Economic and Social Review (Pakistan: 2012), vol. 50, No.2, pp.207-222

${ }^{8}$ Alfaro, Chanda, Ozken and Syek, "How does Foreign Direct Investment promote economic growth?" Exploring the effects of financial markets on linkages. Journal of Development Economics (USA: 2000). pp. $242-256$

${ }^{9}$ Irfan, Mehmood and Farid “ Domestic Investment, Foreign Direct Investment, and Economic Growth Nexus: A Case of Pakistan”. (Pakistan: Hindawi Publishing Corporation Economics Research International, 2014), Article ID 592719, p.5

${ }^{10}$ Behname: "Foreign Direct Investment and Economic Growth: Evidence from Southern Asia". Atlantic Review of Economics, (Iran: 2012), pp.1-14

${ }^{11}$ Koojaroenprasil "The Impact of Foreign Direct Investment on Economic Growth: A Case Study of South Korea". International Journal of Business and Social Science, (Thailand: 2012), vol. 3, No.21; pp.8-19
} 
positive impact of FDI in South Korea and showed a substantial effect. While, nationwide investments have not shown any important effect in progress of nation.

Gezahegne $^{12}$ analyze the Sub Shaharan African countries regarding impact of FDI. By taking data from 1992-2009, he considered physical capital, human capital and external debts as important factors for growth of an economy and he also suggested that if countries enhance human capital and maintain firm macroeconomic environment then they will be able to accomplish their targeted economic growth.

Ahmed et al. ${ }^{13}$ investigated the link between FDI and economic process in Asian country, by taking the fundamental quantity from 1971 to 2007. From this study they came to know that FDI is vital factor in development of an economy and they also found that that political instability is harmful for FDI. The study suggested that government should take incentives to facilitate the investors to enhance the investment of Pakistan and should also ensure political stability.

Attari et al. ${ }^{14}$ studied the effects of FDI in Pakistan by taking time of 1982 to 2009 . The study used unit root test and Granger Causality technique. They used various variables in which includes gross domestic product, FDI, imports and exports as variables. From this study it is concluded that the link is for long-run amongst foreign direct investment and growth.

Younus, Sohail and Azeem ${ }^{15}$ studied the significance of FDI on economic growth of Pakistan by taking time series data of 2000- 2010. Two- Stage least squares method was used in this study. They found positive link of FDI with growth of economy. Younus et al. recommended that to enhance FDI in Pakistan, government should fix the problem of political instability and reassure more domestic investment.

Agrawal $^{16}$ examines regarding the links between FDI and economic process within the BRICS economies by taking time period of 1989 to 2012 and that they get the result that FDI and economic process are co-integrated at the panel level, and that hey conjointly found the existence of a lasting relationship between each variables.

Tang $^{17}$ examines the effects of flow of foreign capital on the economic development of European Union over the time of 1987-2012. This study found that the higher provoke by the European Monetary Union have not contributed to economic growth.

\footnotetext{
${ }^{12}$ Gezahegne, Economic Growth and Foreign Direct Investment in Sub-Saharan African Countries: A Panel Data Analysis. (Ethiopia: Addis Ababa University, 2012)

${ }^{13}$ Ahmad, Hayat, Luqman and Shafqat, "The Causal Links Between Foreign Direct Investment and Economic Growth in Pakistan". European Journal Of Business And Economics 8:, 2012

${ }^{14}$ Attari, Kamal and Nasim "The Causal Link Between Foreign Direct Investment (FDI) and Economic Growth in Pakistan Economy", The Journal of Commerce 2009, pp 3:61-68

${ }^{15}$ Younus, Sohail and Azeem "Impact of foreign direct investment on economic growth in Pakistan", World Journal of Economic and Finance, (2014), vol. 1(1), pp. 002-005

${ }^{16}$ Agrawal "Foreign Direct Investment and Economic Growth in BRICS Economies: A Panel Data Analysis", Journal of Economics, Business and Management, (2015), vol. 3, No.4.

${ }^{17}$ Tang, "Has the Foreign Direct Investment Boosted Economic Growth in the European Union Countries?",

Journal of International and Global Economic Studies, (2015),vol. 8(1), pp 21-50
} 
Bengoa et.al. ${ }^{18}$ studied about the link among foreign direct investment and economic progress by taking data of eighteen Latin American countries for the time of 1970 to 1999. They found a progressive and important impact of FDI on the economic process of the host countries.

Esther and Folorunso ${ }^{19}$ have explored the impact of flows of FDI on economic growth by considering Nigeria. The study found that FDI has a valuable influence on the economic growth. Nevertheless, they also found that there is a direct relationship between FDI and growth of economy but it could be limited by human capital.

Falki $^{20}$ investigates the role of FDI in Pakistan's economy. In this study those variables are been used which effect growth other than FDI like labor, trade and domestic capital. Ordinary least square and unit root techniques has been used in this study. This study found inverse and insignificant link among GDP and FDI in Pakistan. The study suggests that government should take incentives to encourage the foreign investors that will lead to cause positive and significant impact on Pakistan economy.

Eregha $^{21}$ investigated the impact of FDI on African countries. According to their research, FDI inflow to Africa is low but it has positive impact on economic growth of domestic investment. This research also found that foreign direct investment inflow is mainly depending on the policies of country, reliability, institutions and consistent financial sector.

Mamoun, Benmamoun, and Lehnert studied the effects of FDI, worker remittances and official development assistance (ODA) on the progress of developing countries. The research used panel data from 1990 to 2006.They found that there's vital and positive effect of FDI, remittances and ODA on the development of developing nations.

Khan and $\mathrm{Khan}^{22}$ studied about the sectorial analysis on FDI growth of nation. This study found that Pakistan has enormous probable to invite FDI. But, FDI inflows are congested by ineffective legal institutions, weakness of institutions, low labor productivity, political instability, corruption, weak regulatory systems and poor law and order.

Lehman worked on emerging markets and the role of FDI in: Income, repatriations and financial vulnerabilities in Brazil and Argentina by taking data for the period 1996-2000. They found that foreign direct investment is accountable for causing enormous change in external accounts of a country. Host country risks and trade are found to increase profitability of foreign direct investment.

\footnotetext{
${ }^{18}$ Bengoa, M., and Sanchez-Robles, "FDI, Economic Freedom, and Growth: New Evidence from Latin America", European Journal of Political Economy, (2003), vol.19, pp.529-545.

${ }^{19}$ Eregha, The Dynamic Linkages Between Foreign Direct Investment and Domestic Investment in ECOWAS

Countries: a Panel Cointegration Analysis," in Proceedings of the Conference of the Centre for the Study of African Economics, (UK: Oxford University, 2011).

${ }^{20}$ Falki "Impact of foreign direct investment on economic growth in Pakistan," (International Review of Business Research, 2009), vol.5, pp.110-120

${ }^{21}$ Eregha, Op.cit. pp.208-220

${ }^{22}$ Khan and Khan" Foreign Direct Investment and Economic Growth": Sectoral analysis, ( PIDE: 2011), p.67
} 
Dar, Bhatti and Muhammad ${ }^{23}$ studied about foreign direct investment and economy of Pakistan. The study used panel cointegration and VECM model methodology and used human capital, infrastructure, institutions and domestic investment as control variables. For their study they categorized economy of Pakistan into primary, secondary and tertiary sectors. The results of panel approach showed the significant link between FDI and GDP in long and short run. Only in primary sector foreign direct investment showed short run relationship with GDP.

Moudatsou $^{24}$ studied about Economic Growth and FDI in European Union. The data from 1980-1996 of European Union countries have been used. The study found that past FDI inflows have considerable and direct relation with economic growth. The study also came to know that the FDI does not depend on human capital in developed countries.

Acaravci and Ozturk ${ }^{25}$ studied about exports, FDI and economic growth of new EU countries. This research also examines the causative links between exports, FDI, and economic growth of European countries by taking data from 1994 to 2008. The ARDL model has been used to inspect the long term association amongst economic growth, exports and FDI. The outcomes indicated that there is causative relation between export, FDI and economic process in four countries out of 10. They additionally came to grasp that the advance of foreign direct investment depends on the policies of a nation to market FDI.

\title{
Data and Methodology
}

This study will find the effect of FDI and economic growth in context of Pakistan. To check the stationary of data Augmented Dickey Fuller is used. Simple regression method is implemented to estimate the association amongst FDI and economic growth in Pakistan. We will use secondary data of 31 years from 1985 to 2016 in our study. The data for all variables is taken from World Development Indictor (WDI). By following Saqib et al (2013), we will consider the below model

$$
\mathrm{GDP}=\beta 0+\beta 1 \mathrm{FDI}+\beta 2 \operatorname{Exp}+\mu
$$

Where,

\author{
GDP indicates G0ross Domestic Product \\ Exp indicates exports \\ $\mu$ indicates error term
}

\footnotetext{
${ }^{23}$ Dar, Bhatti and Muhammad, "FDI and Economic Growth in Pakistan: A Sector-wise Multivariate Cointegration Analysis". PIDE Working Paper, 2015

${ }^{24}$ Moudatsou" Foreign Direct Investment and Economic Growth in the European Union. ”Journal of Economic Integration 18(4), December 2003; 689-707 PIDE Working Papers, pp 20-21

${ }^{25}$ Acaravci and Ozturk, "Foreign Direct Investment, Export and Economic Growth: Empirical Evidence from New EU Countries", (Turkey: Institute for Economic Forecasting, 2012).
} 


\section{Variables}

In this study three different variables have been considered, GDP, FDI and exports. Here we have taken GDP as explained variable and FDI and exports as explanatory variables. In our research we will attempt to investigate the connection between the foreign direct investment and gross domestic product that by what means foreign direct investment cause the economic process in West Pakistan.

\section{Augmented Dickey Fuller (ADF) Test}

There is always found non-stationarity in the time series data. To make this data stationary and to remove the problem of non-stationarity we will use the unit root test (Augment Dickey Fuller test).

\section{Stationary on level}

\begin{tabular}{|c|c|cc|c|c|}
\hline Variables & ADF & \multicolumn{2}{|c|}{ Critical values } & p-values & conclusion \\
\hline GDP & -3.767577 & $1 \%$ & -3.699871 & 0.0413 & Stationary \\
& & $5 \%$ & -2.976263 & & \\
\hline FDI & -4.537647 & $10 \%$ & -2.627420 & & \\
& & $5 \%$ & -2.661661 & 0.0011 & Stationary \\
& & $10 \%$ & -2.619160 & & \\
\hline Exports & -5.055666 & $1 \%$ & -3.661661 & 0.0003 & Stationary \\
& & $5 \%$ & -2.960411 & & \\
& & $10 \%$ & -2.169160 & & \\
\hline
\end{tabular}

Source: Estimations of researchers

\section{Results}

The above results expressed that data is stationary at level. Because all the critical values are less than absolute ADF values and all the P-values of variables are less than 0.1 and therefore FDI and GDP are stationary at level. On level all the variables are full filling the conditions for stationarity.

\section{Results of Ordinary Least Square}

\begin{tabular}{crlrr}
\hline \hline Variable & Coefficient & Std. Error & t-Statistic & Prob. \\
\hline \hline C & 4.098359 & 0.350227 & 11.70201 & 0.0000 \\
FDI & 0.015541 & 0.005539 & 2.805624 & 0.0089 \\
Exports & 0.027378 & 0.026790 & 1.021937 & 0.3153 \\
\hline \hline R-squared & 0.237335 & Durbin-Watson stat & 1.294387 \\
Adjusted R-squared & 0.184738 & F-statistic & & 4.512286 \\
\hline \hline
\end{tabular}

Source: Estimations of researchers 


\section{Results}

In the above table the adjusted R2 is 0.184738 which means that $18 \%$ of change occurs in the in GDP due to the change in independent variables. Durbin Watson Stat detects the presence of auto correlation. Here the DW stat is less than 2 which shows that there is no autocorrelation between the variables. If autocorrelation is exist in the model then, the statistic will lie somewhere between 2 and 4 . According to our study we can find by the P-value which is 0.008 , that FDI has positive and significant relation with GDP but, exports have positive and insignificant relation with gross domestic product because its $\mathrm{P}$ value is greater than 0.05 .

\section{Conclusions}

In our study we talk over the correlation between FDI and economic growth for economy of Pakistan. The study aims to find out the impact of independent variables which are FDI and exports on GDP in Pakistan for period of 1985 to 2016. In this study we tend to test the impacts of independent variables either they are substantial or insignificant for economic growth. Thus, for our objective we take time series data of Pakistan for the time of 1985-2016. After that we used simple regression model to captures the relationship among the variables. The findings showed that there is direct correlation among dependent and independent variables. FDI has significant impact on GDP but exports have insignificant impact on GDP. From all of our estimations we found that foreign direct investment is a considerable element for development determinations as it has direct and significant impact on growth of an economy. Because FDI is a significant factor for an economy so, government should take steps to attract the foreign investors and make policies to encourage the trade liberalization to gain more from the foreign investment.

\begin{tabular}{|r|r|r|r|}
\hline \multicolumn{1}{|c|}{ Years } & \multicolumn{1}{|c|}{ GDP \% } & \multicolumn{1}{c|}{ FDI \% } & exports \% \\
\hline 1985 & 7.592114699 & 131.3418863 & -0.360031031 \\
\hline 1986 & 5.501653664 & -23.6079326 & 32.80837916 \\
\hline 1987 & 6.452343025 & 3.544559777 & 11.98963795 \\
\hline 1988 & 7.62527878 & 57.73851823 & -4.31256943 \\
\hline 1989 & 4.959768894 & -3.587425406 & 13.77469376 \\
\hline 1990 & 4.458586815 & 45.24783378 & 1.124973794 \\
\hline 1991 & 5.061567755 & 7.741851514 & 33.46522988 \\
\hline 1992 & 7.705897823 & 32.7703383 & 13.82098063 \\
\hline 1993 & 1.757747697 & 0.761554503 & 1.317358064 \\
\hline 1994 & 3.737415552 & 19.77346026 & 3.110662873 \\
\hline 1995 & 4.96260915 & 71.93366145 & -3.075315015 \\
\hline 1996 & 4.846581284 & 26.71891637 & 1.994558492 \\
\hline 1997 & 1.014396014 & -19.08052093 & -6.535973067 \\
\hline
\end{tabular}




\begin{tabular}{|c|c|c|c|}
\hline 1998 & 2.550234295 & -38.42560729 & -5.72997209 \\
\hline 1999 & 3.660132744 & 12.06140351 & -2.850317063 \\
\hline 2000 & 4.260088012 & -41.87866928 & 16.01600127 \\
\hline 2001 & 1.982484032 & 18.51851852 & 12.18324647 \\
\hline 2002 & 3.224429973 & 125.8522727 & 9.960030232 \\
\hline 2003 & 4.846320935 & -35.22012579 & 28.37740916 \\
\hline 2004 & 7.368571359 & 106.2135922 & -1.527826381 \\
\hline 2005 & 7.667304271 & 103.0131827 & 9.59048957 \\
\hline 2006 & 6.177542036 & 93.13543599 & 9.895027393 \\
\hline 2007 & 4.832817277 & 31.89241114 & 1.50972772 \\
\hline 2008 & 1.701405465 & -1.875455208 & -4.552083006 \\
\hline 2009 & 2.831658519 & -57.93282613 & -3.361178732 \\
\hline 2010 & 1.606691959 & -12.88045876 & 15.70766001 \\
\hline 2011 & 2.74840255 & -36 & 2.372197794 \\
\hline 2012 & 3.50703342 & -38.13291139 & -15.00084242 \\
\hline 2013 & 4.396456633 & 43.35038363 & 13.58083445 \\
\hline 2014 & 4.674707981 & 55.66458519 & -1.480176254 \\
\hline 2015 & 4.712457804 & -45.21489971 & -6.343528474 \\
\hline 2016 & 5.741025215 & -100 & -4.761278041 \\
\hline
\end{tabular}

